
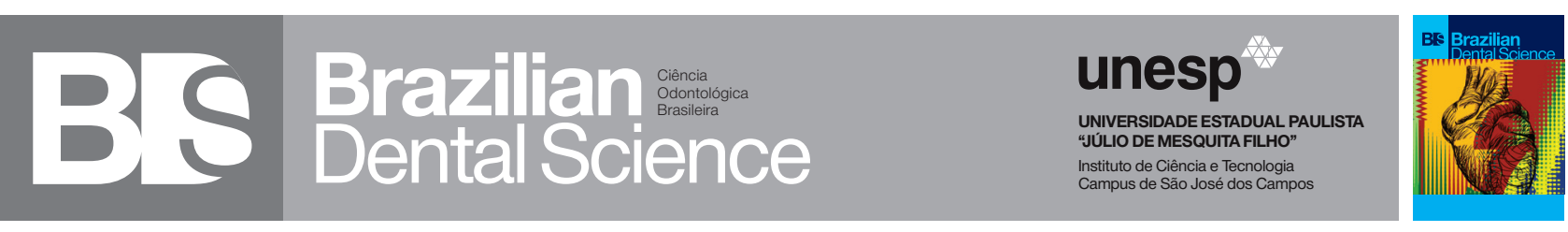

\title{
Chronic kidney disease and periodontal disease. Case report.
}

Doença renal crônica e tratamento periodontal. Relato de caso

\begin{abstract}
Camilla Magnoni Moretto NUNES ${ }^{1}$, Camila Lopes FERREIRA ${ }^{1}$, Daniella Vicensotto BERNARDOํ․ Andréa Carvalho de MARCO ${ }^{2}$, Mauro Pedrine SANTAMARIA ${ }^{2}$, Maria Aparecida Neves JARDINI ${ }^{2}$

1 - São Paulo State University (Unesp) - Institute of Science and Technology - São José dos Campos - Department of Biosciences and Oral Diagnosis - SP - Brazil.

2 - São Paulo State University (Unesp) - Institute of Science and Technology - São José dos Campos - Department of Diagnosis and Surgery - SP - Brazil.
\end{abstract}

\begin{abstract}
Chronic renal disease promotes a decrease on kidneys filterability and nitrogen products accumulation on blood, electrolyte and system endocrine functions imbalance. Among the many clinical manifestations of chronic renal failure (CRF) in the oral cavity, there are: dry mouth, uremic stomatitis, radiographic changes in maxillary and jaw bones and accumulation of calculus on the teeth that increases levels of periodonto pathogenic microorganisms able to lead a periodontal tissue destruction and also have the potential to act from a distance on other organs, e.g. the kidneys. Thus, it becomes evident that a periodontal treatment of patients suffering from chronic renal failure is crucial for maintaining their general health conditions and a subsequent successful organ transplant.Thus, the objectives of this case report were to highlight how important the periodontal treatment is for chronic renal failure patients and to demonstrate improvements in their clinical condition through the treatment plan proposed herein. A patient with 43 years old carrier generalized moderate chronic periodontitis and CRF was submitted to scaling and root planning sessions, and later surgical access for scaling where the basic treatment not resulted in a resolution of the inflammatory periodontal process. The results obtained from a well-developed periodontal treatment and an effective cooperation of patient showed satisfactory results with periodontal disease process resolution or stabilization.Thus, periodontal treatment and patient compliance were crucial for the improvement of periodontal clinical conditions enabling a future successful renal transplantation.
\end{abstract}

\section{KEYWORDS}

Dental care; Periodontal diseases; Renal insufficiency.

\section{RESUMO}

A doença renal crônica promove uma redução na filtrabilidade dos rins e produtos nitrogenados acumulam no sangue promovendo um desequilíbrio eletrolítico efuncional do sistema endócrino. Dentre as diversas manifestações clínicas da doença renal crônica (DRC) na cavidade bucal estão: xerostomia, estomatite urêmica, alterações radiográficas nos ossos maxilares e mandibulares e acúmulo de cálculo dental que eleva os níveis de microrganismos periodontopatogênicos capazes de promover a destruição periodontal e também a capacidade de agir à distância em outros órgãos, como por exemplo, os rins. Dessa forma, torna-se evidente que o tratamento periodontal de pacientes que sofrem com a doença renal crônica é crucial para a manutenção de sua saúde geral e para o subsequente sucesso no transplante de órgão. Então, os objetivos deste relato de caso foram evidenciar a importância do tratamento periodontal para pacientes renais crônicos e demonstrar a melhora na condição clínica através do plano de tratamento proposto. Um paciente de 43 anos de idade, portador de periodontite crônica moderada generalizada e de DRC foi submetido às sessões de raspagem e alisamento radicular, e posteriormente, acesso cirúrgico para raspagem onde o tratamento básico não resultou na resolução do processo inflamatório periodontal. Os resultados obtidos a partir de um tratamento periodontal bem conduzido e uma efetiva cooperação do paciente mostraram resultados satisfatórios com a resolução ou estabilização da doença periodontal. Desta forma, o tratamento periodontal e a cooperação do paciente foram cruciais para a melhora das condições clínicas periodontais possibilitando um sucesso no futuro transplante renal.

\section{PALAVRAS-CHAVE}

Assistência odontológica; Doenças periodontais; Insuficiência renal. 


\section{INTRODUCTION}

C hronic renal disease is characterized by a slow, progressive and irreversible decrease in the number of functional nephrons. In afflicted individuals, this structural alteration decreases the kidneys filtering capacity, thus leading to uremia, i.e. the accumulation of nitrogenous products in the bloodstream, such as urea and creatinine that should have been filtered and excreted by the kidneys [1,2]. According to Siviero et al.[3], this condition is due to the natural process of population aging and the increasing number of carriers of diabetes mellitus and arterial hypertension, which are the most commonly associated morbidities.

Among other clinical manifestations of chronic renal failure (CRF) in the oral cavity, there are: xerostomia, uremic stomatitis and radiographic changes in maxillary and jaw bones, which are secondary to bone calcium loss. This occurs due to a decrease in glomerular filtration rate that results in an increase in serum phosphorus concentration [4], which leads to an increased production of parathyroid hormones whose main functions are to activate osteoclasts, stimulate calcium resorption by the renal tubules and increase calcium absorption by the intestine under normal circumstances.

However, CRF causes the development of hyperparathyroidism, thus leading to the occurrence of osteitis fibrosa in cases of bone tissue being replaced with a fibrous tissue $[5,6]$.

Dental calculus formation is another important recurrent oral manifestation, which is a consequence of an increased concentration of serum calcium and phosphorus [4]. With the formation of dental calculus and depending on the host's susceptibility, as in the case of patients suffering from CRF, periodontopathogenic microorganisms are able to colonize and promote the destruction of periodontal tissues, as well as stimulate the patients' immune system thereof [7].
Thus, the importance of periodontal dental treatment in CRF cases lies on the fact that the prevalence and severity of periodontal diseases have been observed more frequentlyin such patients and, therefore, the oral cavity becomes a possible source of infection[4,8,9].C-reactive protein, interleukin-6 (IL-6) and immunoglobulins, such as IgGs, are some of the inflammatory mediators that are produced while bacterial reactions are taking place in the periodontium, which also have the potential to act from a distance on other organs, e.g. the kidneys, through the bloodstream. Moreover, their increased levels of these mediators are associated with impaired renal functions and possible organ transplant rejection[4,10].

Thus, it becomes evident that a periodontal treatment of patients suffering from chronic renal failure is crucial for maintaining their general health conditions and a subsequent successful organ transplant.

Thus, the objectives of this case report were to highlight how important the periodontal treatment is for chronic renal failure patients and to demonstrate improvements in their clinical condition through the treatment plan proposed herein.

\section{RESULTS}

Patient F.A.G., male, aged 43 years, has been to the College of São José dos Campos Dentistry - UNESP ICT, with a complaint about the presence of an infection focus on the tooth is found waiting to undergo transplantation. The patient's medical history has revealed the presence of chronic renal failure and hypertension, the occurrence of a myocardium heart attack in 2012 and only 8\% operating capacity of the two kidneys. In addition, the patient was anemic, had to undergo hemodialysis three times a week, and therefore had an arteriovenous fistula in the right arm. 
In the first dental treatment, the patient's medical history was reviewed, in which it was found the use of the following medicaments: Losartan (50 mg/2x/day), Atenolol (50 mg/2x/ day), Diurit (20 mg/day), Aas (100 mg/day), Allopurinol (300 mg/day), Omeprazole (20 mg/ day), Atorvastatin (10 mg/day), Alfapoetina (25 U.I./kg/ 3x/week) and Renagel (800 mg/2x/ day). Furthermore, it was written a letter to the nephrologist responsible for prescribing medications during the dental treatment.

In the inicial serological exams was observed $7.5 \mathrm{mg} / \mathrm{dL}$ of calcium, $6.2 \mathrm{mg} / \mathrm{dL}$ of phosphorum, 46.50 of Ca x P and $60 \mathrm{mg} / \mathrm{dL}$ of alkaline phosphatase.

Each consultation was necessary to perform the prophylactic antibiotic therapy, although it is not recommended for patients suffering from CRF according to the American Heart Association. Nevertheless, it was still performed because, according to Guevara et al. [9] patients undergoing hemodialysis are more susceptible to developing infectious processes due to general health conditions in which the immune system efficiency can be compromised[2]. These findings are in agreement with Montero et al.[11], who had reported cases of bacterial endocarditis between 2.7 and $9 \%$ of these patients. Thus, the same protocol was used in this case, i.e. $500 \mathrm{mg}$ amoxicillin administration once a day, and 3 days before the dental procedure for adjusting the dosage according to the patient's renal condition [12].

In addition, in the case of CRF patients undergoing dialysis, there is a high risk of bleeding which is attributed to the combination of using anticoagulants, such as heparin, the presence of average hematocrit of $25 \%$ (indicative of the ratio of circulating red blood cell volume which is being reduced due to a decrease in the production of erythropoietin by the kidneys), and reduced platelet count $[2,9,10]$. Thus, the dental treatment day did not coincide with the hemodialysis day.

Although it was requested not to use anesthetics with vasoconstrictors during the dental treatment, Chioca et al.[13] revealed that felypressin is a synthesized analogue of vasopressin or ADH hormone which is normally produced by the posterior pituitary so as to regulate the blood pressure. Unlike the $\mathrm{ADH}$ hormone that acts on V1 and V2 receptors, felypressin acts only on the V1 receptors which are present on the blood vessel wall, thence promoting their vasoconstriction.

Therefore, it is safe to be used in dental procedures which require a small amount for local anesthesia, due to not inflicting damage to the cardiovascular system. At an initial clinical examination, it was observed the absence of right maxillary $1^{\text {st }}, 2^{\text {nd }}$ and $3^{\text {rd }}$ molars, right maxillary central incisor, left maxillary central incisor, left maxillary $1^{\text {st }}, 2^{\text {nd }}$ and $3^{\text {rd }}$ molars, left mandibular $2^{\text {nd }}$ and $3^{\text {rd }}$ molars and right mandibular $3^{\text {rd }}$ molar. Additionally, there was a grade I furcation lesion in right maxillary $1^{\text {st }}$ bicuspid, right maxillary 1 st molar and left mandibular $1^{\text {st }}$ molar, and a grade II furcation associated with grade 1 mobility in right mandibular $2^{\text {nd }}$ molar. (Figures 1, 2 and 3). 

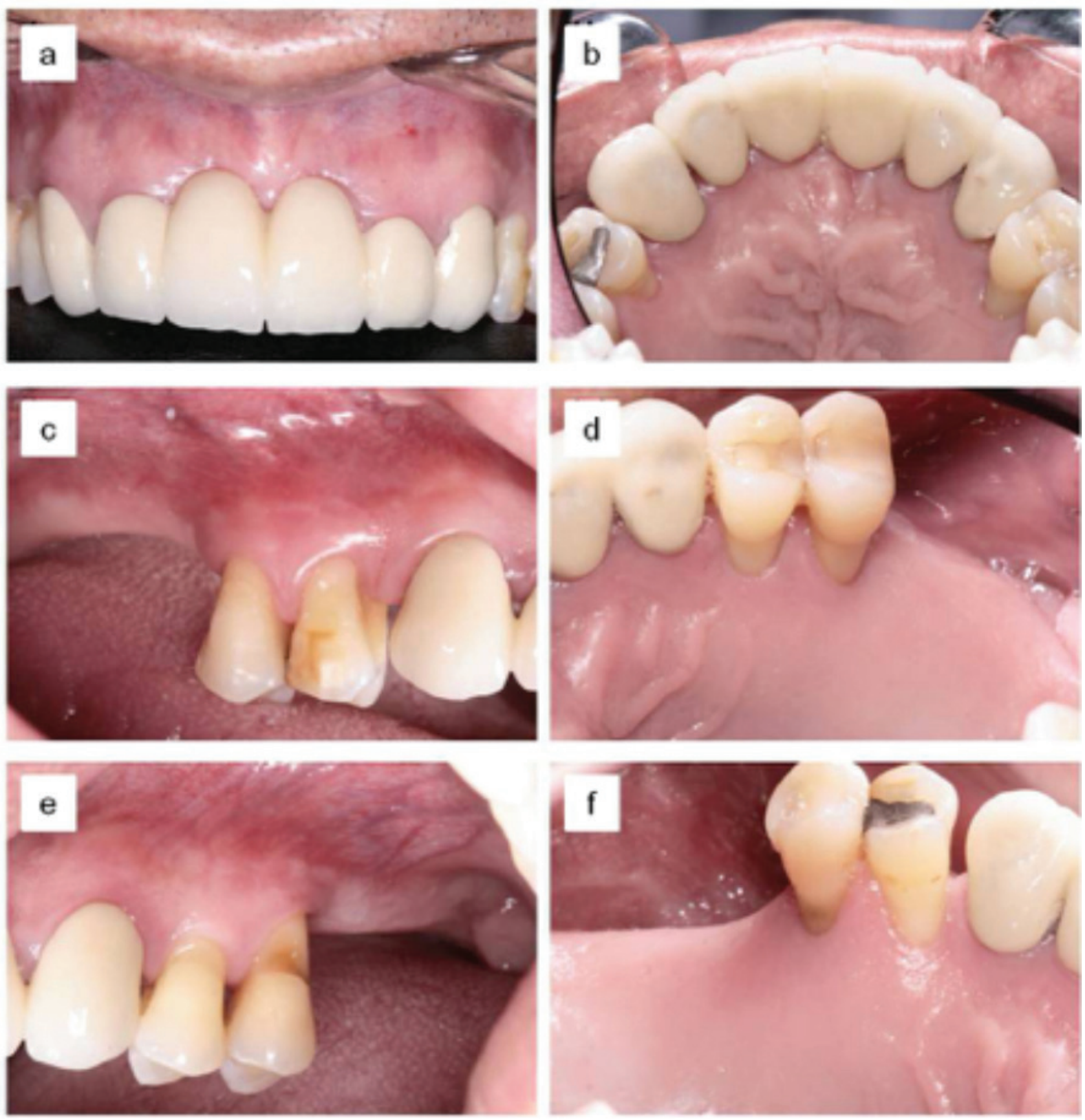

Figure 1 - Images of patient's initial condition on maxillary arch. a) $2^{\circ}$ quadrant buccal, b) $2^{\circ}$ quadrant lingual, c) $1^{\circ}$ quadrant buccal d) $1^{\circ}$ quadrant lingual, e) $3^{\circ}$ quadrant buccal, f) $3^{\circ}$ quadrant lingual. 

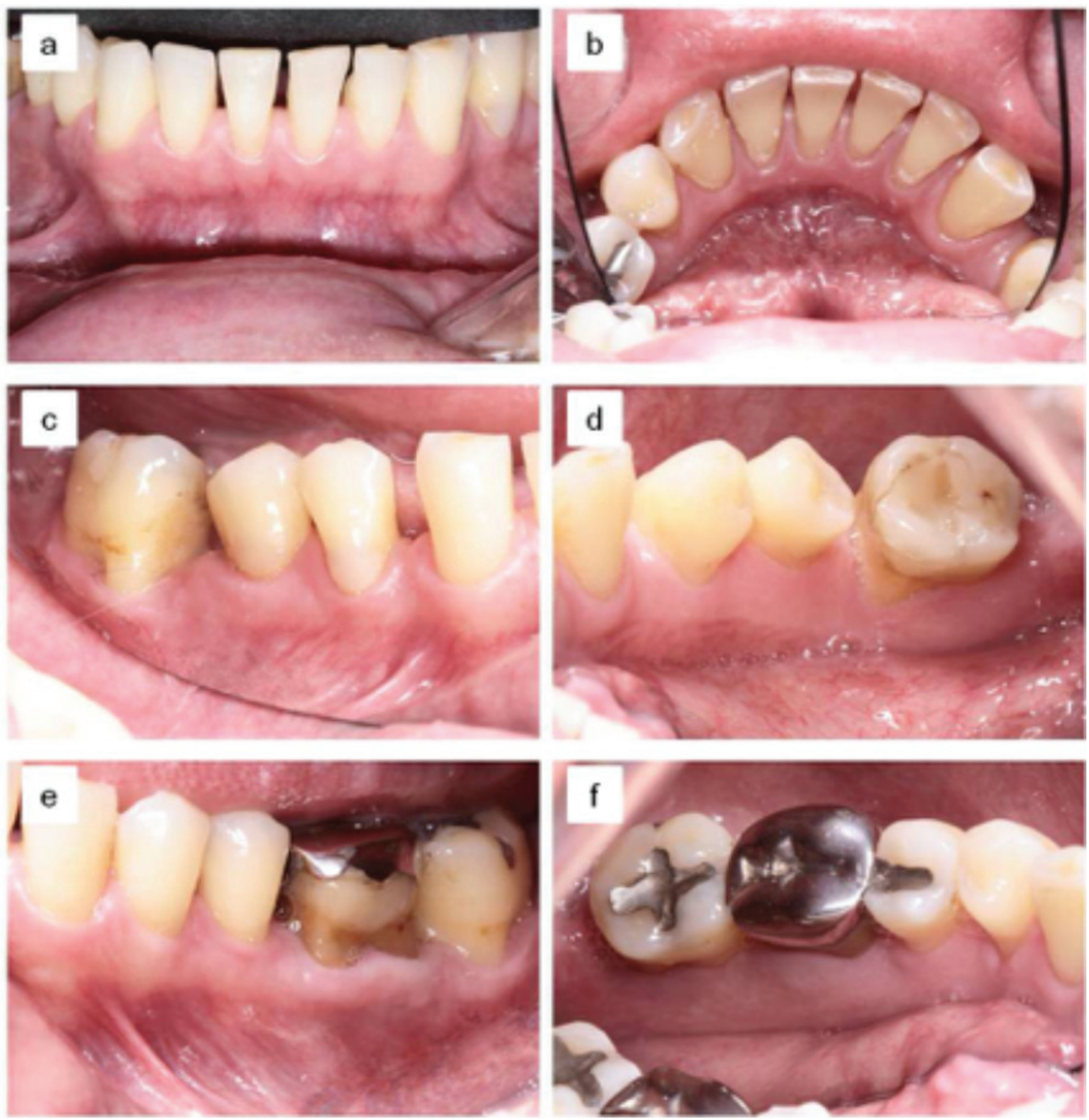

Figure 2 - Images of patient's initial condition on mandibular arch. a) $5^{\circ}$ quadrant buccal, b) $5^{\circ}$ quadrant lingual, c) $4^{\circ}$ quadrant buccal d) $4^{\circ}$ quadrant lingual, e) $6^{\circ}$ quadrant buccal, f) $6^{\circ}$ quadrant lingual. 


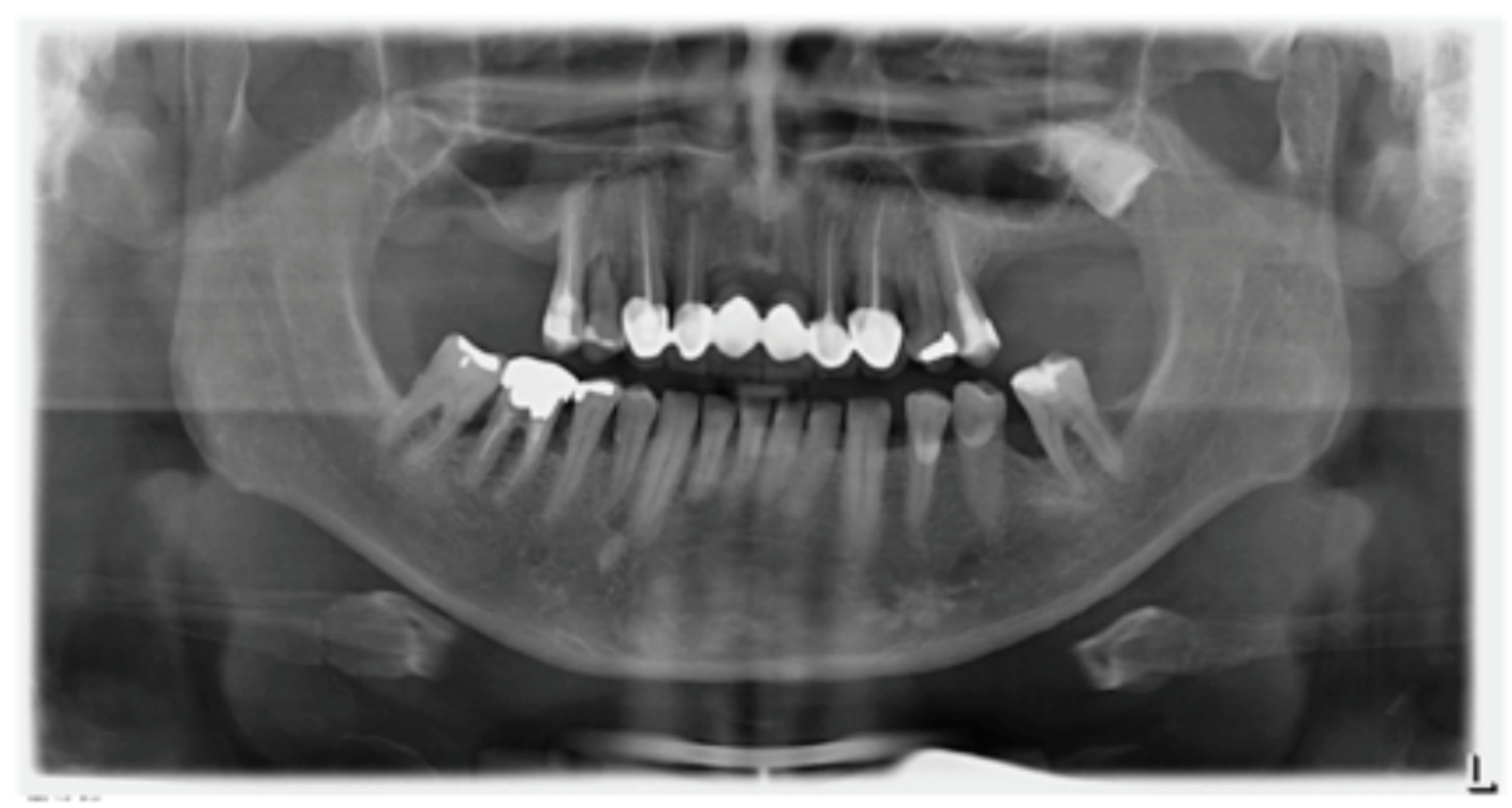

Figure 3 - Initial panoramic radiograph.

Thus, the treatment plan consisted primarily in guidance on the patient's systemic condition and its relationship with periodontal disease [14], followed by a prophylactic therapy phase with oral hygiene orientation sessions (stained plaque exam, type of brush, brushing technique, flossing and interdental brush in diastema interproximal regions) and occlusal-distal restoration with glass ionomer cement in left maxillary 1st bicuspid. Basic therapy with scaling and root planning (hand curettes and ultrasound device) associated with $0.12 \%$ chlorhexidine digluconate rinsing for a better biological response of tissues to the administered periodontal treatment $[15,16]$.

Furthermore, potential sources of infection should also be removed [2], given that the plaque and bleeding indexes along the probing were $88.09 \%$ and $72.61 \%$, respectively.

After a period of seven months of monthly evaluations and scaling and root planning, a reevaluation of the patient's condition was carried out and it was found that there was a reduction in probing depth, though there was some bleeding along a few probing sites. Therefore, in these areas, the surgical therapy is performed with surgical access for scaling (retail Kirkland, 1931) in right mandibular 1st and 2nd molars where the basic treatment has not resulted in a resolution of the inflammatory periodontal process, but with reduced relative initial probing depth and visible plaque and bleeding indexes of $3.57 \%$ and $2.38 \%$, respectively.

After another assessment that required a further period of one month, it was found that the patient had no clinical signs of periodontal inflammation, and was thus allocated to support periodontal therapy(Figures4, 5,and 6).Also a new serological exams was required and showed $8.6 \mathrm{mg} / \mathrm{dL}$ of calcium, $3.4 \mathrm{mg} / \mathrm{dL}$ of phosphorum, 29.34 of $\mathrm{Ca} \times \mathrm{P}$, and $63 \mathrm{mg} / \mathrm{dL}$ of alkaline phosphatase. 

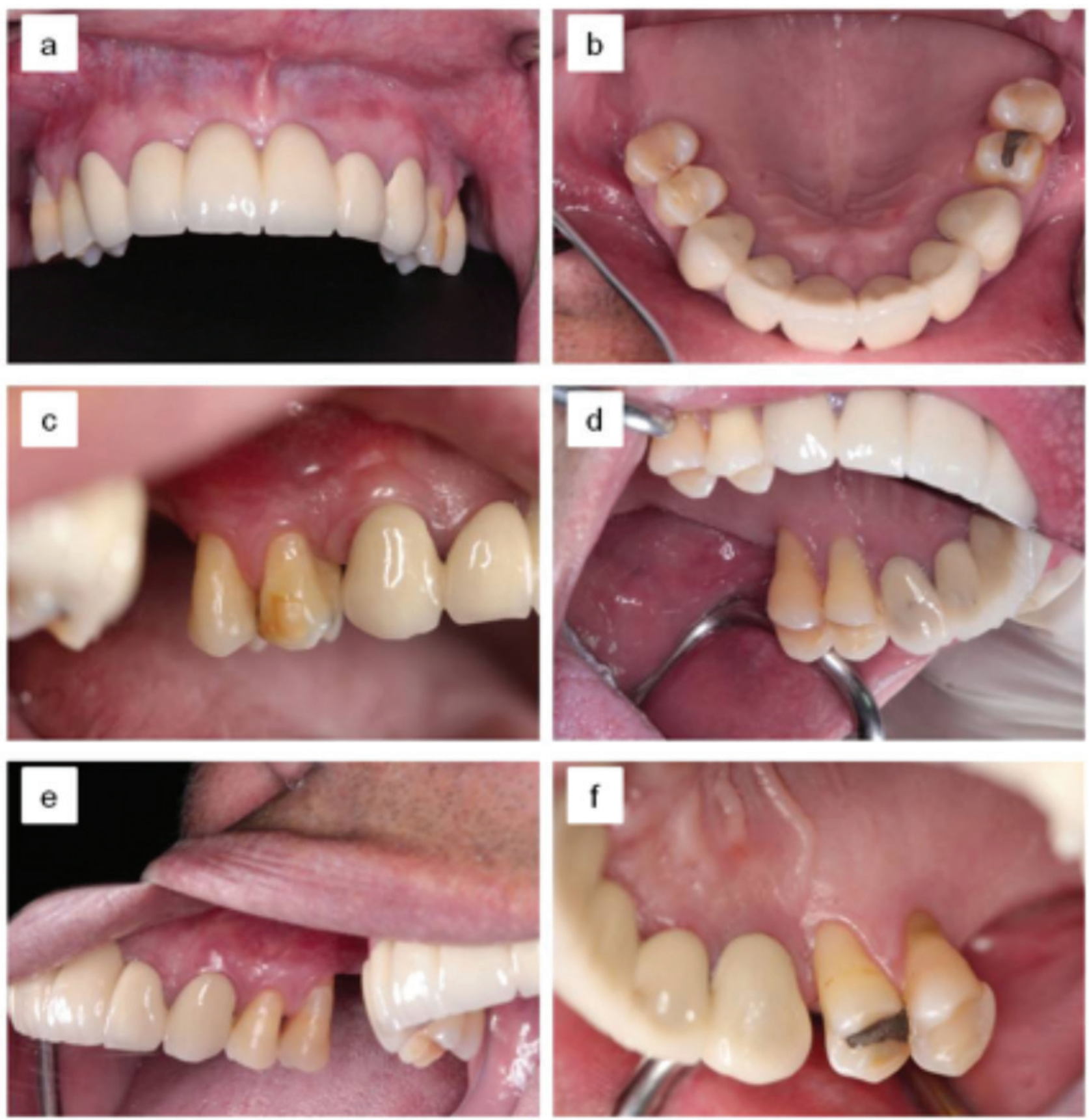

Figure 4 - Images of patient's final condition on maxillary arch. a) $2^{\circ}$ quadrant buccal, b) $2^{\circ}$ quadrant lingual, c) $1^{\circ}$ quadrant buccal d) $1^{\circ}$ quadrant lingual, e) $3^{\circ}$ quadrant buccal, f) $3^{\circ}$ quadrant lingual. 

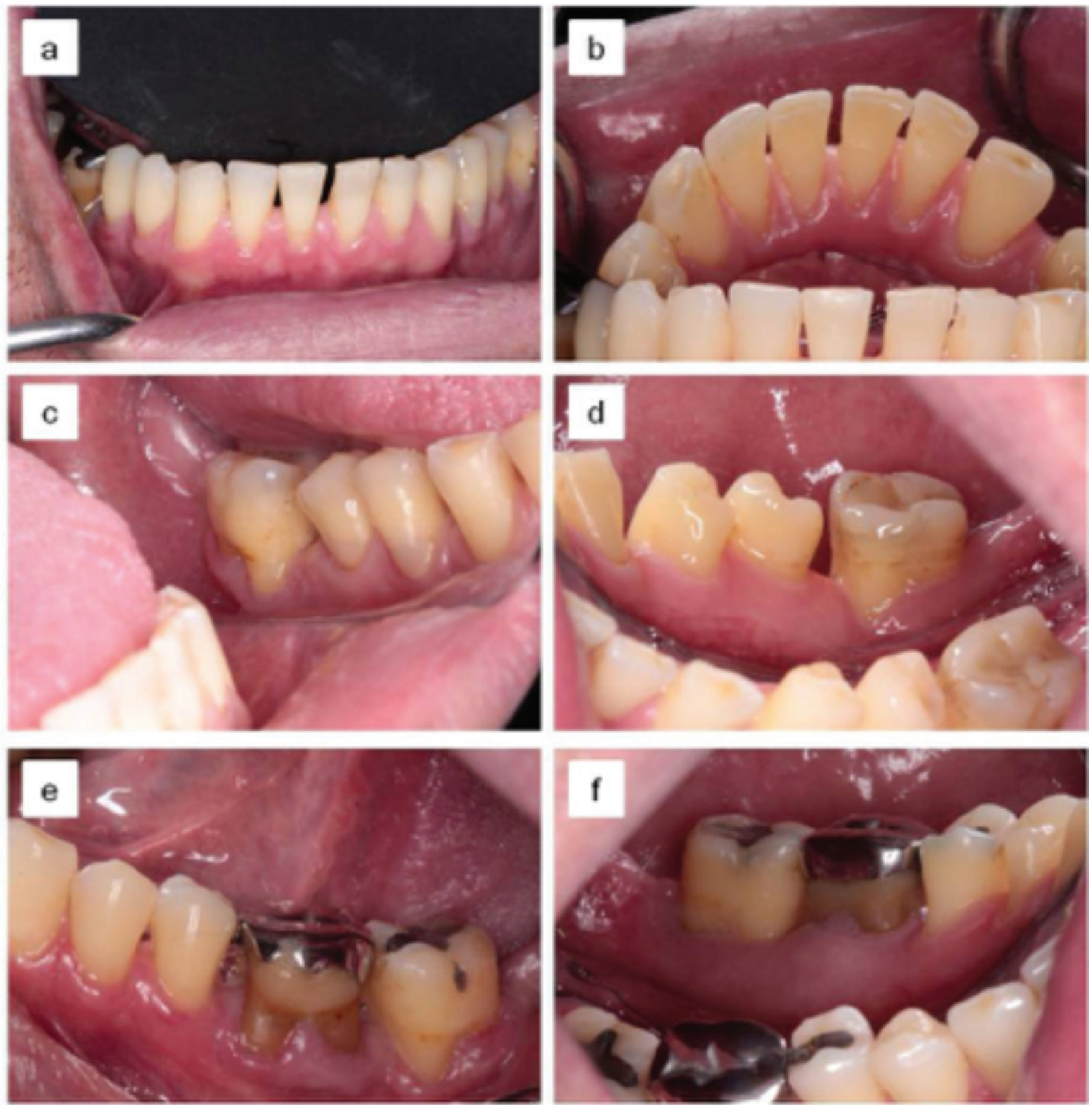

Figure 5 - Images of patient's final condition on mandibular arch. a) $5^{\circ}$ quadrant buccal, b) $5^{\circ}$ quadrant lingual, c) $4^{\circ}$ quadrant buccal d) $4^{\circ}$ quadrant lingual, e) $6^{\circ}$ quadrant buccal, f) $6^{\circ}$ quadrant lingual. 


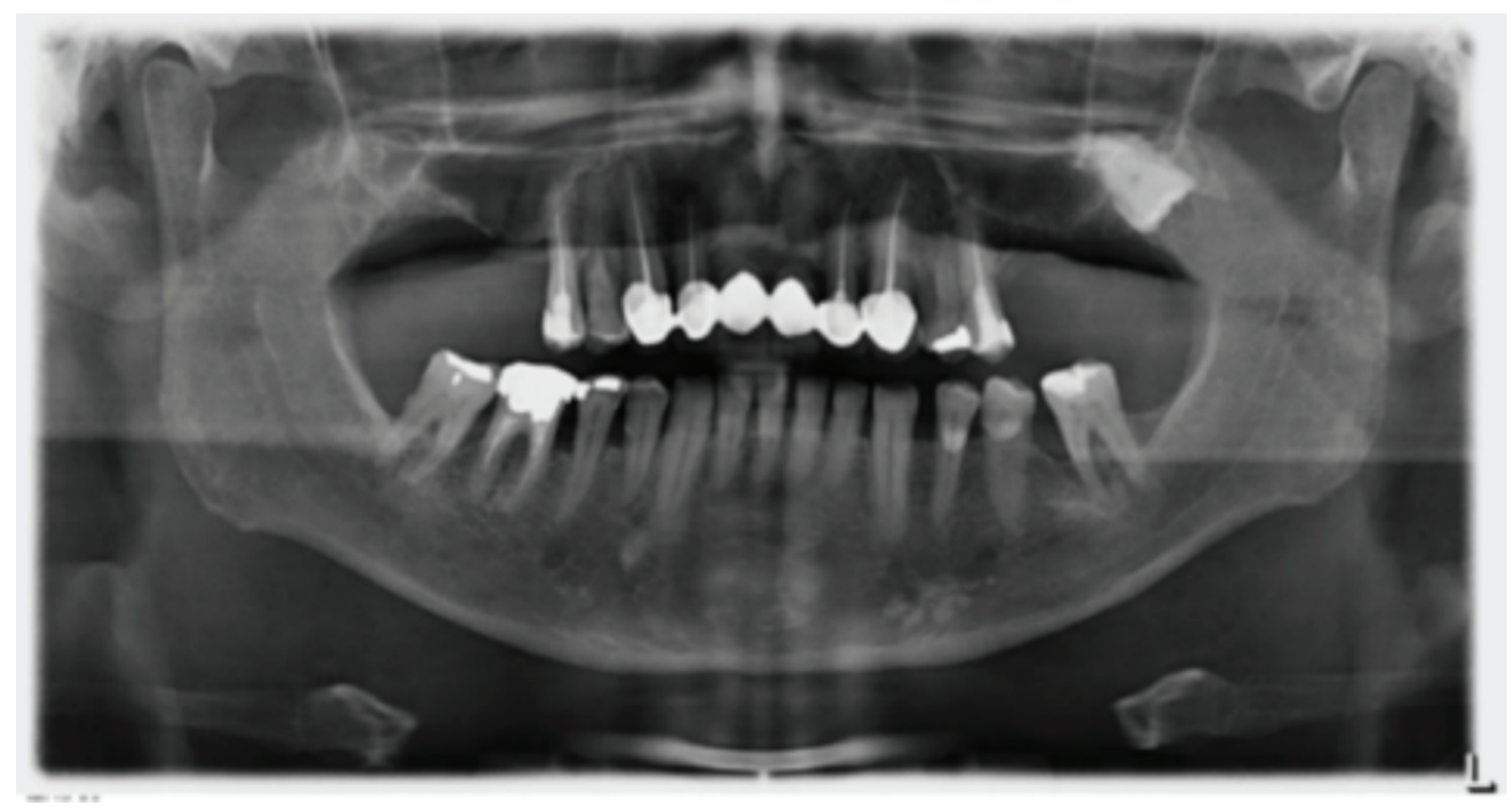

Figure 6 - Final panoramic radiograph.

\section{DISCUSSION}

Chronic renal failure is a disease which is characterized by a slow and progressive loss of nephrons function due to structural or functional abnormalities of the kidneys. Thus, blood changes may be observed, such as anemia, increased urea and creatinine during urination due to a reduction of glomerular filtration rate, hyperparathyroidism, hypertension, cardiovascular disorders, immunological $[2-4,14]$ and oral manifestations as xerostomia, uremic stomatitis, radiographic changes in the jaw bone tissue, dental calculus formation, tooth mobility, among others[4].

Periodontal disease (PD) as a chronic inflammation of the supportive tissues of the teeth, leads to an uncontrolled increase in immunoglobulins and cytokines production, such as IgG; IL-6 and TNF- $\alpha$, which will trigger increased bone resorption, besides the very destruction of the periodontal tissues [7]. Chronic inflammation, also commonly found in CRI, is associated with anemia in such patients because erythropoiesis can be inhibited by various proinflammatory cytokines at higher concentrations, such as IL-1, IFN- $\gamma$ and TNF- $\alpha[14]$.

The presence of high amounts of these immunoglobulins for both the periodontal pathogens and the inflammatory process itself, according to Kshirsagar et al. [17], is associated with decreased kidney function. Moreover, it has been observed the severity and prevalence of PD in CRF patients if compared to the general population [4]. Therefore, the periodontal disease can also be considered an important risk factor for chronic renal patients.

The mechanisms of action of this two-way relationship between PD and CRF can be explained from the observations made by several studies in periodontal tissues. Among these observations, it is noted that low immunity, systemic inflammation and bacterial products in the periodontium lead to worsening the $\operatorname{CRF}[1,14,18]$ due to an increased production of proinflammatory cytokines 
inflammatory. Another example is set by changes in the metabolism of calcium, phosphorus and parathyroid hormone that lead to greater action of cytokines IL-1, IL- 6 , IFN- $\gamma$ and TNF- $\alpha$ which will act on bone metabolism, an important factor in the progression of periodontal disease. Besides the increase in serum calcium concentration, uremia promotes alteration in the biofilm $\mathrm{pH}$ and, consequently, it also leads to an increased deposition of calculus on tooth surface $[14,19]$.

The inflammatory process promoted by both the CRF and the PD, according to Almeida et al. [14], is the main factor that correlates these diseases, i.e. the potential of the inflammatory response promoted by PD generates a systemic inflammatory burden that influences the CRF which, in addition to risk factor, can be a deterrent for kidney transplantation [20,21]. Thus, it is highlighted the importance of oral health of patients with chronic renal failure during the stages of hemodialysis and post-transplant.

Through periodontal therapy, the incidence and severity of PD can be controlled in these patients. In addition, an improvement can be observed in the patient's dental health and a reduction of inflammatory marker indexes, thus improving their quality of life $[2,14]$.

Thence, another important factor that should be taken into consideration is the psychoemotional state of these patients who are often not aware of the importance of maintaining oral health and its impact on the course of kidney disease and transplant success[1,14,20,22].

Although there are many complications involved in the process of chronic kidney disease and that the presence of aggravating factors, especially the periodontal disease, are often observed in these patients $[2,4,14]$. The results obtained from a well-developed periodontal treatment and with an effective and responsible cooperation of patients showed satisfactory results, as it could be observed in this case report with reduced bleeding indexes along probing and plaque removal, as well as the elimination of periodontal pockets, i.e. the interruption or delay of progression of periodontal destruction [18].

\section{CONCLUSION}

Through this case report, we want to attract attention of dental professionals for periodontal treatment concernment in afflicted patients with chronic renal disease. Furthermore, increase knowledge of this complex relationship between the two diseases for better treatment of these patients.

\section{ACKNOLEDGMENTS}

Conflict of Interest and Financing.

The authors declare that they have no personal, business, academic, political or financial interests in this manuscript.

\section{REFERENCES}

1. Oliveira CS, Artese HPC, Silva AG, Delgado A, Torres MCMB. Manifestações bucais e doença renal crônica - revisão de literatura. R Periodontia. 2008 Mar;18(1):14-9.

2. Pupo MLMGS,Parizoto GA, Gonzaga CC, Lopes MGK. Índice de risco odontológico para pacientes pré-transplante renal submetidos à hemodiálise. Rev Sul-Bras Odontol. 2010;7(1):50-6.

3. Siviero PCL, Machado CJ, Cherchillia ML. Insuficiência renal crônica no Brasil segundo enfoque de causas múltiplas de morte. Cad Saúde Colet. 2014;22(1):75-85.

4. Gonçalves ÉM, Lima DLF, Albuquerque SHC, Carvalho JA, Cariri TFA, Oliveira, CMC. Avaliação da perda de inserção dentária em pacientes com doença renal crônica em hemodiálise. J BrasNefrol. 2011;33(3):291-4.

5. Guyton AC. Fisiologia Humana. 6ed. Rio de Janeiro; Guanabara Koogan: 1984. $564 \mathrm{p}$.

6. Martins CTB, Jorgetti V. Hiperparatireoidismo secundário e resposta imune.J BrasNefrol. 1995;17(2):85-89.

7. Silveira VRS, Alves APNN. Perfil celular e mediadores químicos na doença periodontal associada ao biofilme dental-revisão de literatura. R Perio. 2009;19(3):73-9.

8. Bastos MG, Bregman R, Kirsztajn GM. Doença renal crônica: frequente e grave, mas também prevenível e tratável. RevAssocMedBras 2010;56(2):248-53.

9. Guevara HG, LoMonaco G, Rivero CS, Vasconcellos V, Souza DP, RaitzR. Manejo odontológico em pacientes com doença renal crônica. RevBrasCiên Saúde. 2014;:12(40):74-81.

10. Neto JFT,Penteado LAM. Doença periodontal em paciente renal - revisão de literatura. RPerio. 2009Dec;19(4):23-9. 
11. Montero SR, Basili AE, Castellón LZ Manejo odontológico del paciente coninsuficiencia renal crónica. RevDent Chile. 2002;93(2):14-8.

12. Wannmacher L, Ferreira MBC. Farmacologia clínica para dentistas. 3 ed. Guanabara-Koogan;2007.p 321-327.

13. Chioca LR, Segura RCF,Andreatini R, Losso EM. Antidepressivos e anestésicos locais: interações medicamentosas de interesse odontológico. Rev Sul-Bras Odontol. 2010 Oct-Dec;7(4):466-73.

14. Almeida DC, Pereira CS, Granjeiro JM, Machado WAS, Tostes FRV, Barboza ESP. A relação bidirecional entre doença periodontal e doença renal crônica: da progressão da doença renal crônica à terapia renal substitutiva de diálise. $R$ Perio. 2011Mar;21(1):73-9.

15. Drisko CH. Non-surgical pocket therapy: pharmacotherapeutics. Ann Periodontol. 1996 Nov;(1):491-566.

16. Matesanz-PérezP,García-Gargallo M,Figuero E,Bascones-Martínez A, Sanz $M$, Herrera D. A systematic review on the effects of local antimicrobials as adjuncts to subgingival debridement, compared with subgingival debridement alone, in the treatment of chronic periodontitis. J ClinPeriodontol. 2013 Mar;40(3):227-41. doi:10.1111/jcpe.12026. Epub 2013 Jan 16.
17. Kshirsagar AV, Offenbacher S, Moss KL, Barros SP,Beck JD. Antibodies to periodontal organisms are associated with decreased kidney function. BloodPurif. 2007;25(1):125-32. Epub 2006 Dec 14.

18. Bezerra VLMM, Leitão RFC,Brito GAC, Rocha FAC,Ribeiro RA. Principais mediadores inflamatórios envolvidos na fisiopatologia da periodontite -Papel de moduladores farmacológicos. R Perio. 2008 Sep;18(3):7-19.

19. Thorman R, Neovius M, Hylander B.Clinical findings in oral health during progression of chronic kidney disease to end-stage renal disease in a Swedish population. Scand JUrolNephrol. 2009;43(2):154-9.

20. Kovesdy CP. Rate of kidney function decline associates with increased risk of death. J Am SocNephrol. 2010;21(11):1814-6.

21. Um YJ, Jung UW, Kim CS, etal. The influence of diabetes mellitus on periodontal tissues: a pilot study. J Periodontal ImplantSci. 2010 Apr;40(2):4955. doi: 10.5051/jpis.2010.40.2.49. Epub 2010 Apr 15.

22. Borawski J,Wilczynska-Borawska M,Stokowska W,Mysliwiec M. The periodontal status of pre-dialysis chronic kidney disease and maintenance dialysis patients. Nephrol Dial Transplant 2007 Feb;22(2):457-64. Epub 2006 Nov23.

\section{Maria Aparecida Neves Jardini}

\section{(Corresponding address)}

Department of Diagnosis and Surgery

Av. Eng. Francisco José Longo, 777 - Jardim São Dimas

São José dos Campos - SP/Brazil CEP: 12245-000

Date submitted: 2017 0ct 27

jardini@ict.unesp.br 